\title{
Scl-70 Antibody
}

National Cancer Institute

\section{Source}

National Cancer Institute. SC1-70 Antibody. NCI Thesaurus. Code C122770.

An anti-nuclear autoantibody that recognizes a $70 \mathrm{kDa}$ fragment of DNA topoisomerase

1. It is associated with scleroderma. 